\title{
Ice loss processes in the Seal Nunataks ice shelf region from satellite altimetry and imagery
}

\author{
Christopher SHUMAN, ${ }^{1}$ Ted SCAMBOS, ${ }^{2}$ Etienne BERTHIER ${ }^{3}$ \\ 1 JCET, UMBC, NASA Goddard Space Flight Center, Greenbelt, MD, USA \\ E-mail: Christopher.A.Shuman@nasa.gov \\ ${ }^{2}$ NSIDC, CIRES, University of Colorado at Boulder, Boulder, CO, USA \\ ${ }^{3}$ LECOS, Université de Toulouse, CNES, CNRS, IRD, UPS, Toulouse, France
}

\begin{abstract}
The Seal Nunataks ice shelf (SNIS, $\sim 743 \mathrm{~km}^{2}$ in 2013) is an unofficial name for a remnant area between the former Larsen A and Larsen B ice shelves off the northeastern Antarctic Peninsula. Analyses using Landsat 7 ETM+ and Terra ASTER images from 2001 to 13 and ICESat altimetry from 2003 to 09 show it has retreated and thinned following the Larsen A (1995) and Larsen B (2002) disintegrations. Despite some regional cooling and more fast ice since 2008, SNIS continues to lose ice along its margins and may be losing contact with some nunataks. Detailed analysis of data from four ICESat tracks indicates that ice shelf thinning rates range between 1.9 and $2.7 \mathrm{~m} \mathrm{a}^{-1}$, and generally increase from west to east. An ICESat repeat track crossing the adjacent Robertson Island shows a mean elevation loss of $1.8 \mathrm{~m} \mathrm{a}^{-1}$. Two tracks crossing the SNIS's remaining tributary, Rogosh Glacier, show sub-meter elevation losses. Comparing shelf remnant and grounded ice thinning rates implies that basal ocean melting augments SNIS thinning by $\sim 1 \mathrm{~m} \mathrm{a}^{-1}$, a rate that is consistent with other estimates of oceandriven shelf thinning in the region.
\end{abstract}

KEYWORDS: Antarctic glaciology, ice shelves, remote sensing

\section{INTRODUCTION}

The loss of the Larsen A ice shelf in 1995 (Rott and others, 1996; Rack and others, 1999) and the Larsen B ice shelf in 2002 (Scambos and others, 2003) has had long-term consequences for the northern Antarctic Peninsula (nAP) ice cover. Foremost among these are a rapid increase in ice flux from tributary glaciers flowing into the former ice shelf areas, along with continued calving and weakening of remnant shelf ice following the break-ups. These changes have been well documented by a large number of researchers studying the region's ice shelf and tributary glaciers (e.g. Rignot and others, 2004; Scambos and others, 2004; Glasser and others, 2011; Khazendar and others, 2015; Seehaus and others, 2015; Wuite and others, 2015) and geologic environment (Nield and others, 2014). The events and responses are relevant to ongoing processes on other ice shelf areas around Antarctica (Rignot and others, 2013; Paolo and others, 2015). A series of studies have quantified the contributions to sea level rise that this region has made in recent decades as a result of increased glacier flux (Rignot, 2006; Rott and others, 2011; Shuman and others, 2011; Berthier and others, 2012; Scambos and others, 2014).

Since the collapses, two ice shelf remnants have remained within the Larsen A and B embayments. The northern fragment, informally named the Seal Nunataks ice shelf (SNIS), is $\sim 750$ $\mathrm{km}^{2}$ (in 2013) remnant braced by more than a dozen rocky nunataks of volcanic origin (Fig. 1 and Table 1) (GonzálezFerrán, 1983; Global Volcanism Program, 1982). SNIS is currently the northernmost Antarctic ice shelf area larger than $10 \mathrm{~km}^{2}$. At its eastern end, the SNIS is connected to a small ice cap on Robertson Island (RI) $\left(\sim 160 \mathrm{~km}^{2}\right.$ in 2012). At its western end, the SNIS receives ice influx from the Rogosh Glacier (RG), a $\sim 27 \mathrm{~km}$ long glacial tributary flowing south and east from the main ice sheet of the nAP. The southern ice shelf fragment, the Scar Inlet ice shelf (SIIS), is bounded by the nAP coast to the west and Jason Peninsula to the south and east. The SIIS was $1870 \mathrm{~km}^{2}$ in 2012 (Wuite and others, 2015). Despite being fed by two large glaciers, this remnant has experienced ice area losses (e.g. http://earthobservatory.nasa.gov/IOTD/view.php?id=6354) as well as other changes such as ice velocity and shear margin weakening (Khazendar and others, 2015; Wuite and others, 2015).

The present study explores recent changes in the region of the SNIS remnant and attempts to use its unique characteristics to explore both surface ablation rates and to infer ocean-driven basal thinning in the northeastern AP. The SNIS is an excellent target for this work, having low ice velocities of $\sim 25 \mathrm{~m} \mathrm{a}^{-1}$ (Rack and others, 1999; Rignot and others, 2011), low snow accumulation and therefore a low seasonal cycle in elevation (vas Wessem and others, 2016), and near-zero firn air content (Holland and others, 2011). The isolated northerly setting of the SNIS and its consequent near-annual indications of extensive surface melt, means that the firn compaction term can be neglected since the shelf surface layer has been essentially solid ice for the entire study period. Past studies have inferred basal melting as a component of the evolution of ice shelves in this region, such as the Larsen C (Shepherd and others, 2003) but later work (Holland and others, 2011, 2015) has shown that this more southern ice shelf had a more significant firn compaction correction required than the one applied by Shepherd and others. This led to improved estimates of basal melt rates, but concluded that both factors contribute nearly equally to surface lowering (Holland and others, 2015).

The break-up of the Larsen B was thought to be largely climate driven (e.g., Vaughan and Doake, 1996; Scambos and others, 2000; van den Broeke, 2005), but recent studies suggest a significant component of the events leading to 


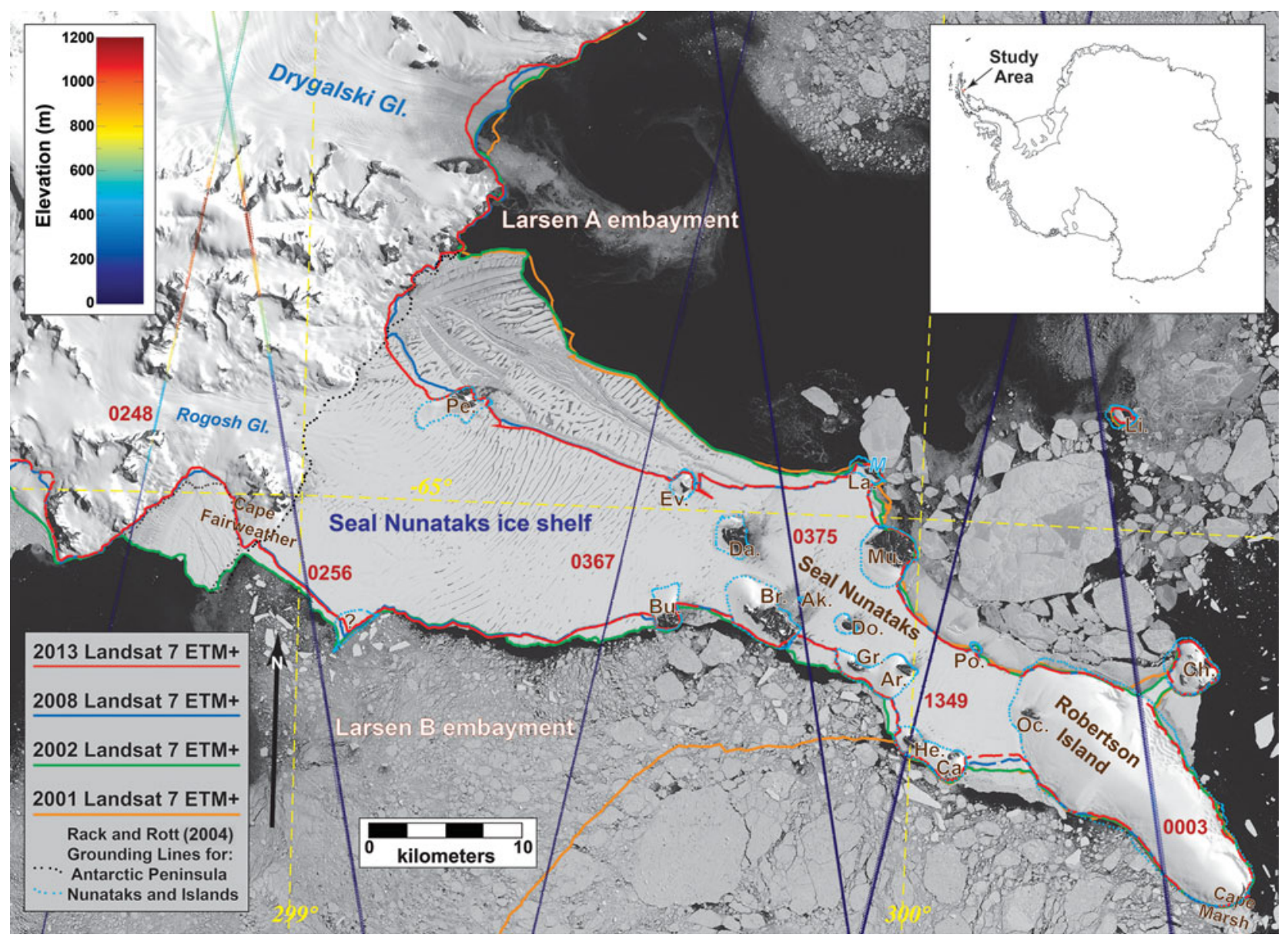

Fig. 1. Location map of the Seal Nunataks study area showing positions of ICESat repeat tracks, names of key geographic features and ice edge changes in the area from 2001 to 2013. ICESat tracks are color-coded for elevation. The names of the individual Seal Nunataks and adjacent islands are abbreviated (see Table 1). The background image is a 28 December 2002 Landsat 7 ETM+ image and additional Landsat images (see Table 2) were used to track overall ice edge changes, indicated by colored lines, across the study area. The Rack and Rott (2004) InSARderived GL positions (colored dots) are shown for the Antarctic Peninsula as well as adjacent nunataks and islands. The Antarctic inset map shows the general position of the study area.

break-up was basal melting (Holland and others, 2015). Thus, an analysis of thinning rates on the remnant SNIS shelf may provide some indication of the rate of ocean-driven melt for the Larsen $A$ and Larsen $B$ region in the period just after the Larsen B disintegration, as well as indications of the causes of ongoing thinning in the remnant SIIS.

\section{METHODOLOGY AND DATASETS}

The methodology for this study can be summarized as follows: we utilized low-cloud-cover visible imagery and selected, nearly-continuous laser altimetry profiles to quantify changes in the past decade for the SNIS and adjacent grounded ice areas. Despite the area's cloudy weather, the data available (Tables 2 and 3) was sufficient to allow the overall timing and magnitude of relatively small area and elevation changes to be analyzed. From the resulting surface elevation change data, we calculated estimated ice thickness changes for the SNIS remnant and compared with those changes in the adjacent grounded ice areas.

\section{Satellite remote sensing imagery}

To analyze the changes to glacial ice in the study area, Landsat 7 Enhanced Thematic Mapper Plus (ETM+) and Terra ASTER visible and near infrared (VNIR) images were used to evaluate shelf area and other physical changes to the SNIS, RI and RG portions of the study area. The imagery data were projected to WGS UTM Grid 20S (ETM+) and 21S (ASTER) and the program QGIS (version 2.10.1 'Pisa', 2015) was used to assess areas within our manually mapped SNIS or RI limits as well as the inland length of the RG. Stereo ASTER images from 2005 were also used to generate a digital elevation model (DEM) of RI (Table 2). For RI area change estimates, we chose to use ASTER imagery to avoid the need to extrapolate across the gaps in the ETM+ imagery that are due to the Scan Line Corrector failure (SLC-off) in 2003; however, this was not practical for the larger SNIS area. Finally, a long-term archive of MODIS imagery, available from the National Snow and Ice Data Center (NSIDC: https://nsidc.org/data/iceshelves_images/ index_modis.html, Larsen B) (Scambos and others, 1996), was used to qualitatively evaluate the presence or absence of extensive fast ice in the adjacent embayments as well as indications of surface melt in the austral summer months particularly when higher resolution imagery (Table 2 ) was not available.

\section{Grounding line (GL) and area estimates}

We chose to use the GL positions derived from interferometric synthetic aperture radar (InSAR) in the late 1990s by Rack 
Table 1. Names of Seal Nunataks features (see Fig. 1)

\begin{tabular}{ll}
\hline Abbreviation & Landscape feature (additional information) \\
\hline Ak. & Akerlundh Nunatak (crossed by ICESat Track 0375) \\
Ar. & Arctowski Nunatak \\
Br. & Bruce Nunatak \\
Bu. & Bull Nunatak \\
Ca. & Castor Nunatak \\
Ch. & Christensen Island* \\
Da. & Dalman Nunatak* \\
Do & Donald Nunatak \\
Ev. & Evensen Nunatak \\
Gr. & Gray Nunatak \\
He. & Hertha Nunatak (crossed by ICESat Track 1349) \\
La. & Larsen Nunatak (location of Base Aérea Teniente \\
Li. & Benjamín Matienzo) \\
Mu. & Lindenberg Island* \\
Oc. & Murdoch Nunatak* \\
Pe. & Ocean Nunatak (at west end of RI, Cape Marsh at east \\
Po. & end of RI) \\
$?$ & Pederson Nunatak \\
& Pollux Nunatak \\
\hline
\end{tabular}

Feature names and indications of volcanism $\left(^{*}\right)$ are from Figure 1 in González-Ferrán (1983) except for the unnamed ice rise. Larsen Nunatak is the location of Base Aérea Teniente Benjamín Matienzo (' $M$ ' in Fig. 1), a seasonal Argentine research station.

and Rott (2004), hereafter called the R\&R-GL, to define the interface between the SNIS and RG and to determine which portions of the ICESat profiles were on and off the SNIS (Fig. 1). Note, the GL was used to define the western limit of the SNIS even though close inspection of recent imagery suggests it has moved inland at RG since it was defined with 1995-99 interferometry. The MOA2004 GL data, defined by breaks or inflections in ice slope (Haran and others, 2005), do not differ significantly from the R\&R GL where the SNIS meets the AP. For the small observed differences, it is not clear if they are due to the different techniques or changes in the ice over time (Depoorter and others, 2013, Supplementary Information, Section 5). As in Haran and others (2005), visual inspection of satellite images was used to identify later GL positions for SNIS and RI.

The image data made it apparent that GL position had changed during the study period as had ice shelf area (Fig. 1; Table 2). To define the SNIS and RI areas, we used surface features observed in the imagery sequence to approximate the overall shelf remnant ice area, including all internal nunataks and to also distinguish it from adjacent grounded ice areas including the RI ice cap. Note, we do not include the ice shelf remnant west of Cape Fairweather and its protruding underwater ridge $\left(\sim 44 \mathrm{~km}^{2}\right.$ in 2002 , lost in early 2004) defined by the GL adjacent to the SNIS area (Fig. 1).

The area values from this analysis (Table 2) have a combined uncertainty from a small amount of measurement error and a larger, but less defined, grounding zone position uncertainty. In the overall SNIS region, we estimate $\sim 10 \mathrm{~km}^{2}$ uncertainty caused by shelf extent/grounded ice extent discrimination. For RI alone, we compared extents digitized from two ASTER images taken $5 \mathrm{~d}$ apart in 2005 (10 and 15 November 2005), which showed a net area difference of $<0.4 \mathrm{~km}^{2}$. This test provides a sense of the measurement error and repeat assessments of single RI scenes produced similar or smaller area differences, but all required using an approximate GL position relative to the adjacent SNIS ice area. The use of ETM+ SLC-off imagery also increases area estimate uncertainties for SNIS as those images require extrapolation across narrow regions without visible data. Based on this, we expect areas to be uncertain at the few $\mathrm{km}^{2}$ level for the ASTER-derived RI areas and $\sim 10 \mathrm{~km}^{2}$ for the ETM + estimates of SNIS.

\section{Satellite laser altimetry}

For all ICESat tracks, we selected repeat profiles with the least cloud obscuration (i.e. complete or essentially complete profiles) of the ice shelf surface and the adjacent ocean and grounded ice areas for further analysis (Table 3). After this initial filtering, the Release 633 data was de-tided, GeoidCentroid bias corrected (Borsa and others, 2014), and then adjusted to a sea level datum. This was done using the average of the lowest 3 elevations in the nearest $2 \mathrm{~km}$ of the profile over the adjacent embayments (Kwok and others, 2004; Scambos and others, 2005). These data were then compared sequentially to assess thinning and margin retreat and anomalous and incomplete tracks were removed. As in Pritchard and others (2012), the CATS2008A tide model (Personal communication from L. Padman, 2014) could not be readily applied because of distinct uncertainties in grounded ice positions within this small area. A discussion of these issues for tide-corrections is found in Griggs and Bamber (2011).

Table 2. Landsat 7 ETM+ and Terra ASTER imagery

\begin{tabular}{llll}
\hline Imagery & $\begin{array}{l}\text { Date } \\
\text { dd/mm/yy }\end{array}$ & Band & $\begin{array}{c}\text { Areas } \\
\mathrm{km}^{2 *}\end{array}$ \\
\hline Landsat 7 ETM+ & $31 / 12 / 2001$ & Band 8, panchromatic & $\begin{array}{l}\text { Pre-collapse } \\
\text { Landsat 7 ETM+ }\end{array}$ \\
Landsat 7 ETM+ & $28 / 12 / 2002$ & Band 8, panchromatic & $992.2 \mathrm{SNIS}$ \\
Landsat 7 ETM+ & $17 / 01 / 2008$ & Band 8, panchromatic & $752.4 \mathrm{SNIS}$ \\
\hline ASTER VNIR & $14 / 01 / 2013$ & Band 8, panchromatic & $743.1 \mathrm{SNIS}$ \\
ASTER VNIR & $26 / 09 / 2001$ & Band 3N & $166.3 \mathrm{RI}$ \\
ASTER VNIR & $18 / 12 / 2002$ & Band 3N & $162.6 \mathrm{RI}$ \\
ASTER VNIR & $15 / 11 / 2005$ & Band 3N,B & $162.1 \mathrm{RI}$ \\
ASTER VNIR & $23 / 03 / 2008$ & Band 3N & $160.4 \mathrm{RI}$ \\
ASTER VNIR & $12 / 01 / 2012$ & Band 3N & $159.2 \mathrm{RI}$ \\
& $28 / 01 / 2012$ (in Fig. 4b) & Band 3N & Not utilized
\end{tabular}

Enhanced Thematic Mapper Plus (ETM+) and Visible and Near Infrared (VNIR). Stereo ASTER images in 2005 provided a digital elevation model (DEM) of Robertson Island ( $\mathrm{N}=$ nadir; $\mathrm{B}=$ back). *See discussion of area measurements and their uncertainty in the text. 
Table 3. Summary of ICESat repeat track data used in the study

\begin{tabular}{|c|c|c|c|c|c|c|c|}
\hline Campaign & Year & 0248 & 0256 & 0367 & 0375 & 1349 & 0003 \\
\hline $2 \mathrm{~A}$ & 2003 & $07 \mathrm{Nov}$ & $07 \mathrm{Nov}$ & $15 \mathrm{Nov}$ & $16 \mathrm{Nov}$ & 21 Oct & 22 Oct \\
\hline $2 B$ & 2004 & 10 Mar & 10 Mar & $18 \mathrm{Mar}$ & 18 Mar & 22 Feb & 22 Feb \\
\hline $2 \mathrm{C}$ & 2004 & 09 June & 09 June & 17 June & 17 June & 23 May & 23 May \\
\hline $3 \mathrm{~A}$ & 2004 & 25 Oct & 26 Oct & $02 \mathrm{Nov}$ & $03 \mathrm{Nov}$ & 08 Oct & 09 Oct \\
\hline $3 \mathrm{~B}$ & 2005 & $12 \mathrm{Mar}$ & $13 \mathrm{Mar}$ & $20 \mathrm{Mar}$ & $21 \mathrm{Mar}$ & 23 Feb & $24 \mathrm{Feb}$ \\
\hline $3 C$ & 2005 & 11 June & 12 June & 19 June & 20 June & 25 May & 26 May \\
\hline $3 \mathrm{D}$ & 2005 & $12 \mathrm{Nov}$ & $12 \mathrm{Nov}$ & $20 \mathrm{Nov}$ & $21 \mathrm{Nov}$ & 26 Oct & 27 Oct \\
\hline $3 \mathrm{E}$ & 2006 & 16 Mar & 16 Mar & $24 \mathrm{Mar}$ & 24 Mar & 27 Feb & 27 Feb \\
\hline $3 \mathrm{~F}$ & 2006 & 15 June & 15 June & 23 June & 23 June & 29 May & 29 May \\
\hline $3 G$ & 2006 & $15 \mathrm{Nov}$ & $16 \mathrm{Nov}$ & $23 \mathrm{Nov}$ & $24 \mathrm{Nov}$ & 29 Oct & 30 Oct \\
\hline $3 \mathrm{H}$ & 2007 & $02 \mathrm{Apr}$ & $03 \mathrm{Apr}$ & $10 \mathrm{Apr}$ & $11 \mathrm{Apr}$ & $16 \mathrm{Mar}$ & 17 Mar \\
\hline 31 & 2007 & 24 Oct & 25 Oct & $01 \mathrm{Nov}$ & $02 \mathrm{Nov}$ & 07 Oct & 08 Oct \\
\hline 3J & 2008 & 10 Mar & 10 Mar & $18 \mathrm{Mar}$ & $18 \mathrm{Mar}$ & 22 Feb & 22 Feb \\
\hline $3 \mathrm{~K}^{*}$ & 2008 & $\mathrm{~N} / \mathrm{A}$ & $\mathrm{N} / \mathrm{A}$ & $\mathrm{N} / \mathrm{A}$ & N/A & 09 Oct & 09 Oct \\
\hline $2 \mathrm{D}^{*}$ & 2008 & 05 Dec & 06 Dec & $13 \mathrm{Dec}$ & $14 \mathrm{Dec}$ & N/A & $\mathrm{N} / \mathrm{A}$ \\
\hline $2 \mathrm{E}$ & 2009 & 30 Mar & 31 Mar & $07 \mathrm{Apr}$ & $08 \mathrm{Apr}$ & $13 \mathrm{Mar}$ & $14 \mathrm{Mar}$ \\
\hline $2 \mathrm{~F}^{*}$ & 2009 & N/A & N/A & $\mathrm{N} / \mathrm{A}$ & N/A & 05 Oct & 06 Oct \\
\hline
\end{tabular}

ICESat's repeat tracks are listed from west to east across the Seal Nunataks ice shelf region. Profile dates are underlined if they provided useful altimetry to the analysis. The notation 'N/A' means the track was not acquired. Partial campaigns are marked with an asterisk. http://nsidc.org/data/icesat/laser_op_periods.html.

Under clear sky and for grounded ice having low slope, ICESat measurements have an uncertainty of $\sim \pm 0.14 \mathrm{~m}$ (Shuman and others, 2006). Later releases of ICESat data had a validated measurement uncertainty of $0.15 \mathrm{~m}$ (Schutz and others, 2011) although performance varied slightly over the mission. As such, RMS elevation differences of $\sim 0.20$ m could exist between exact repeat tracks over an unchanging grounded ice target. For floating ice shelf profiles, the components of elevation uncertainty are discussed in detail as being $\sim \pm 0.275 \mathrm{~m}$ for a single track (Pritchard and others, 2012, Supplementary Information, page 9). Based on this, an RMS of $\sim 0.40 \mathrm{~m}$ might be expected for elevation profile differences from floating ice areas.

\section{Elevation and thickness change estimates}

For the SNIS remnant, we sought to evaluate elevation changes over the maximum time period possible (Table 3) within the ICESat mission. For the grounded ice profiles we used repeat profiles with small laser footprint separations, sometimes limiting the temporal separation of observations. However, because these offsets were usually less than the nominal ICESat laser footprint ( $\sim 70 \mathrm{~m}$, every $\sim 170 \mathrm{~m}$ along track) (Schutz and others, 2005) we were able to minimize cross-track slope impacts on the derived elevation change estimates (Hofton and others, 2013).

\section{SNIS elevation loss estimates}

Figure 2 shows the selected repeat profile data for each track location with the maximum temporal separation. Cloud cover impacted some tracks (e.g. Fig. 2a). Cross-track separations of the Figure 2 profiles ranged from $14 \mathrm{~m}$ for Track 0256 to $111 \mathrm{~m}$ for Track 0367 . However all profiles are in very low slope areas (the SNIS ice shelf surface) except where crossing grounded areas. We further reduced the impact of slope, and of individual measurement noise by taking the average elevations of each ICESat altimetry profile (e.g. the profile positions of the red lines in Fig. 2) and deriving regression lines through those average elevations (Fig. 3).
Although seasonal variations or densification of recent snowfall might impact the observed elevation change results in other regions, we believe that these are not significant issues here given the low annual snow accumulation for the southeastern nAP (van Wessem and others, 2016), and strong seasonal surface melting and re-freezing of the annual snowfall. The linearity of our observed SNIS changes using ICESat campaigns, at periods out of phase with seasonality, suggest that seasonal variations must be small. Moreover, a six-season observational record on the SIIS and four-season record on Cape Disappointment from Automated Meteorology-Ice/ Indigenous species-Geophysics Observation Systems, AMIGOS (Scambos and others, 2013) have never indicated a snowfall event of $10 \mathrm{~cm}$ snow height, and show that the seasonal elevation variation in the region is not more than 20 $\mathrm{cm}$. AMIGOS-related field work by one of us (TAS) and an analysis of elevation and thickness data on SNIS, Larsen B and SIIS (Holland and others, 2011) documents that the 'firn' in this area is ice. The repeated indication of surface melt ponding in summertime satellite imagery is a further indication of impermeable ice at the surface. Based on these lines of evidence, we do not apply a firn-compaction or seasonal elevation correction to these data.

\section{SNIS thickness loss estimates}

In contrast to the analysis in Pritchard and others (2012) and specifically for the SNIS (Personal communication from Pritchard, 2014), firn compaction is essentially nil in the area. Therefore, for the SNIS profiles we assumed all elevation change is directly related to a change in shelf thickness. Further, we assumed that the ice losses detailed in Figure 2 are from shelf areas in hydrostatic equilibrium away from GL positions.

To convert ice elevation changes (Fig. 3) to thickness changes, we modified Eqn (1) from Griggs and Bamber (2009) by eliminating the firn terms. Ice thickness changes at the floating ice positions profiled by ICESat were then determined using the relationship:

$$
\Delta Z=\Delta e \times \rho_{\mathrm{w}} /\left(\rho_{\mathrm{w}}-\rho_{i}\right)
$$



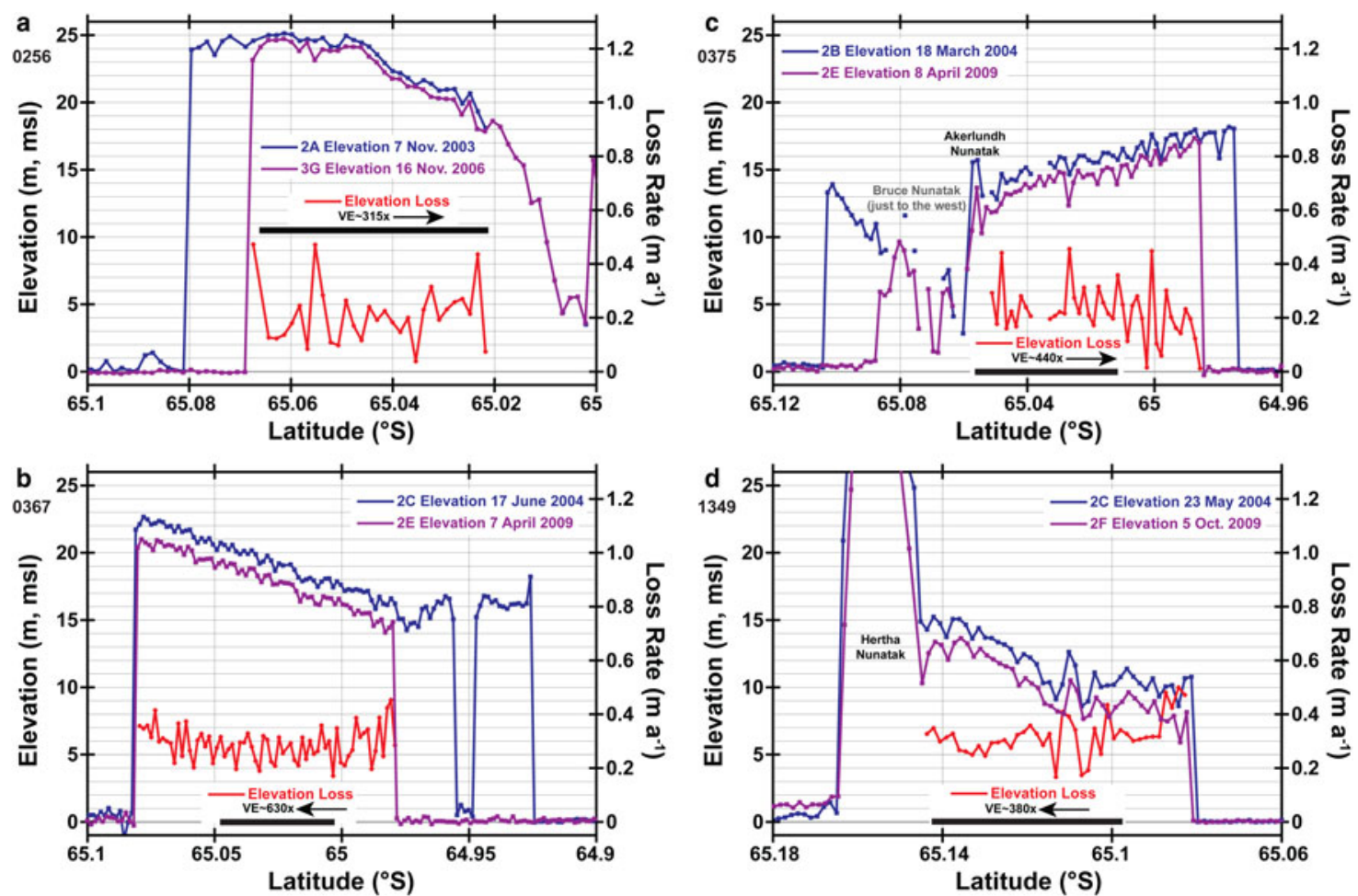

Fig. 2. Elevation profiles and elevation loss rates are derived from the first and last available ICESat track across four parts of the Seal Nunataks ice shelf remnant. The first and last repeat track data show the overall changes to the shelf remnant including iceberg calving and elevation losses. The red lines indicate the magnitude and pattern of the loss rate across each profile. All plots have the same $y$-axis range but different $x$ axis ranges. Missing points are indicated by gaps in the plotted data. ICESat's orbit direction is indicated with the arrow and the degree of vertical exaggeration (VE) of the elevation data is shown in each plot. The black bar indicates $5 \mathrm{~km}$ in distance.

where $\Delta Z$ is change in ice thickness, $\Delta e$ is elevation change from the regression lines in Figure 3, $\rho_{i}$ is the estimated mean density of the ice shelf and $\rho_{\mathrm{w}}$ is the mean sub-ice-shelf water density. We used an average ice shelf density of $900 \mathrm{~kg} \mathrm{~m}^{-3}$ and a seawater density of $1028 \mathrm{~kg} \mathrm{~m}^{-3}$ (Personal communication from B. Huber, 2013) to convert observed elevation to estimated thickness change. This results in an ice shelf freeboard of $0.128 \mathrm{~m}$ for each meter of ice shelf thickness that allows derivation of evolving shelf thickness estimates from the data in Figure 3. For RI and RG profiles, the elevation loss is similarly assumed to be all ice without firn compaction although that approximation may not be the most appropriate for the highest elevation profiles in the study area (e.g. Track 0248 on RG, Fig. 1).

\section{Grounded ice elevation changes}

We differenced repeat profiles with small laser footprint separations for all the grounded ice areas with data on RI and RG. Because these offsets were less than the nominal ICESat laser footprint of $\sim 70 \mathrm{~m}$ (Schutz and others, 2005), cross-track slope impacts on the derived elevation changes

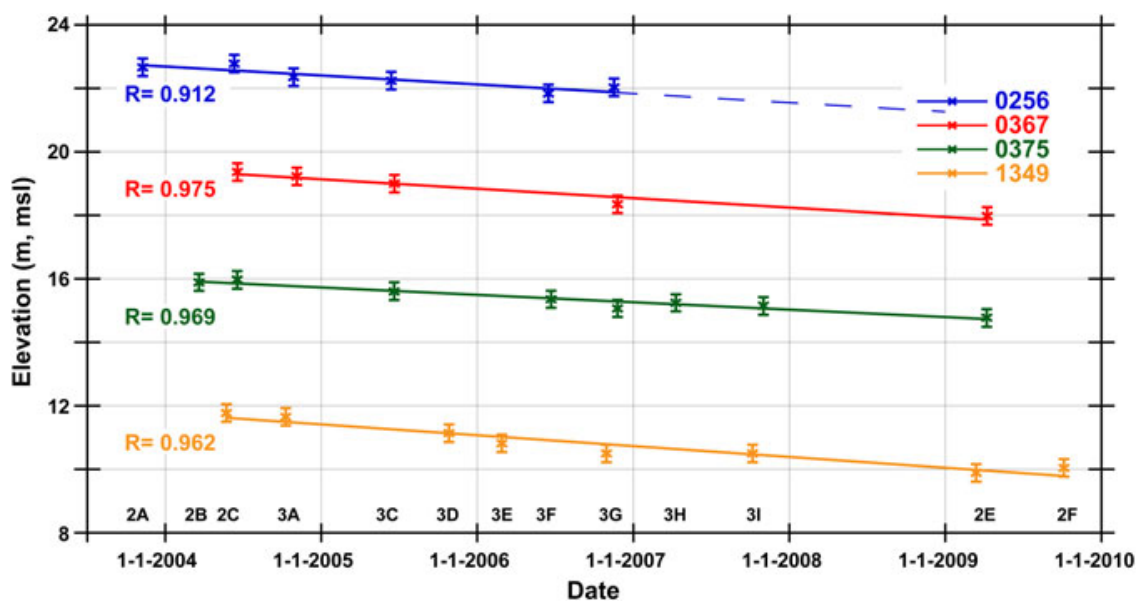

Fig. 3. Plot of the mean elevation of each ICESat repeat profile crossing the remainder of the Seal Nunataks ice shelf remnant during $2003-09$. The ICESat campaigns used in the study are labeled at the bottom of the plot. The regression lines indicate the elevation loss as a function of time and were used to calculate change rates in Table 4. The trend of Track 0256 losses is extrapolated to 2009 (dashed portion) on the basis of its regression line. 

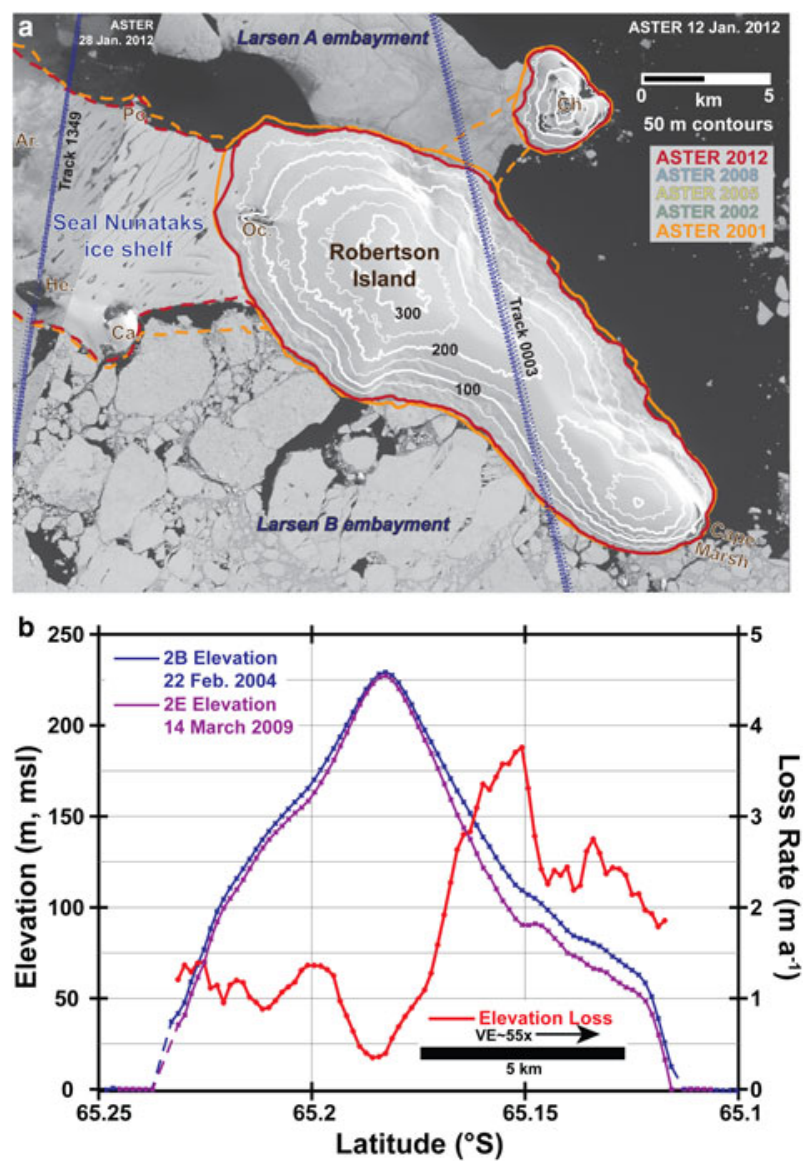

Fig. 4. Changes in the ice cover of Robertson Island (RI) over the study period. Panel a shows the position of Track 0003 across the island and also Track 1349 crossing Hertha Nunatak (He.) as well as the adjacent ice shelf remnant in 2012. Multiple ASTER images were used to define ice edge positions but only the 2001 and 2012 edges are shown here (see Table 2). A 2005 ASTER image pair (Table 2) generated the DEM used for the elevation contours. The dashed lines indicate interpreted ice shelf remnant limits and solid lines are used for island areas. Nearby features are labeled in the same manner as in Figure 1 (Table 1). Panel b shows the first and last Track 0003 elevation profiles as well as the derived elevation change rates. ICESat's direction is indicated with the black arrow and the degree of vertical exaggeration (VE) of the elevation data is shown. The black bar indicates $5 \mathrm{~km}$ in distance. Missing ICESat shots are indicated by dashed lines in the island's profile. were minimal. The footprint separations averaged $38 \mathrm{~m}$ for $\mathrm{RI}^{\prime} \mathrm{s}$ Track 0003 data, $41 \mathrm{~m}$ for the RG's Track 0248 data and $44 \mathrm{~m}$ for the Track 0256 data. We tried to correct the influence of the cross track slopes on RG using an external SPOT5 DEM (Korona and others, 2009) but the procedure was unsuccessful due to the high noise level in the DEM in this area with limited contrast in the imagery. However, the 2005 ASTER DEM for RI (Fig. 4) was successfully utilized as described in Shuman and others (2011, Section 2.2) to correct for cross-track slope variations in the available ICESat data. No Operation IceBridge airborne altimetry data are available over this area. Due to the lack of independent elevation data, profile elevation difference uncertainties are estimated from the standard deviation of the shot-toshot elevation differences ( $\sigma$ values in Table 4).

\section{RESULTS AND DISCUSSION}

During the study period, the SNIS remnant became an increasingly isolated ice mass, bounded by its grounded ice components (RI, RG and adjacent nAP coast), and its nunataks (Fig. 1 and Table 1). Examination of Figure 1 and other imagery used in the study also shows that melt ponds regularly occupied the lows between the generally NE SW trending undulations in the shelf remnant. The undulations are related to the long-term movement of ice from the glacial tributaries, including the RG, to the past Larsen A and B ice shelves.

\section{SNIS ice shelf area changes}

Over the 2001-13 time period, the SNIS ice edges have retreated considerably (Fig. 1; Table 2) (see also Ferrigno and others, 2006, 2008; Cook and others, 2005; Cook and Vaughan, 2010). The SNIS area, not including RI (discussed below) but including embedded nunataks, reduced from $992.2 \mathrm{~km}^{2}$ in 2002 to $743.1 \mathrm{~km}^{2}$ in 2013 , a net loss for this period is $249.1 \mathrm{~km}^{2}$ with an estimated uncertainty of $\sim 10$ $\mathrm{km}^{2}$. The losses on SNIS's north side have been previously indicated for the Larsen A by Cook and Vaughan (2010, their Table 3, Fig. 4.9) but the data in Table 2 specifically track the SNIS's area.

During mapping of the ice shelf area from the image series, the presence and progression of a series of rifts between Ocean and Castor nunataks (see Fig. 4a) was

Table 4. Summary of repeat-track elevation and estimated ice shelf changes

\begin{tabular}{|c|c|c|c|c|}
\hline Track & $\begin{array}{l}\text { Time interval } \\
\text { days (years) }\end{array}$ & $\begin{array}{l}\text { Mean elevation loss }(\sigma) \\
\mathrm{m}\end{array}$ & $\begin{array}{l}\text { Elev. loss rate } \\
\mathrm{m} \mathrm{a}^{-1}\end{array}$ & $\begin{array}{l}\text { Est. thinning rate } \\
\mathrm{m} \mathrm{a}^{-1}\end{array}$ \\
\hline 0256 SNIS & 1104.5 (3.02) & $0.85(0.33)$ & 0.28 & 2.25 \\
\hline 0367 SNIS & $1755.7(4.81)$ & $1.43(0.29)$ & 0.30 & 2.39 \\
\hline 0375 SNIS & $1846.5(5.05)$ & $1.18(0.50)$ & 0.23 & 1.88 \\
\hline 1349 SNIS & $1961.4(5.37)$ & $1.83(0.75)$ & 0.34 & 2.74 \\
\hline $0003 \mathrm{RI}$ & $1846.5(5.05)$ & $8.90(0.83)$ & 1.76 & \\
\hline $0248 \mathrm{RG} N / \mathrm{S}$ & $1846.5(5.05)$ & $1.46(0.58) / 2.94(0.77)$ & $0.29,0.58$ & \\
\hline 0256 RG & $522(1.43)$ & $0.76(0.89)$ & 0.53 & \\
\hline
\end{tabular}

Loss values for the SNIS are derived from the regression lines shown in Figure 3. The losses for RI and RG are the mean elevation differences between the spatially-closest pair of ICESat profiles. As discussed in the text, RG is divided into north $(\mathrm{N})$ and south (S) branches (Fig. 5a). For all the profiles, the elevation loss is also assumed to be without firn compaction. The standard deviations $(\sigma)$ of the derived SNIS elevation losses are from first - last repeats (see Table 3 ) whereas the $\mathrm{RG}$ and RI $\sigma$ values are from spatially closest profile pair. Because of RI's topography accentuates mass losses on the north side, we used data from the lower 200 $\mathrm{m}$ on the south side of the island (25 points) to derive the $\sigma$ value. 

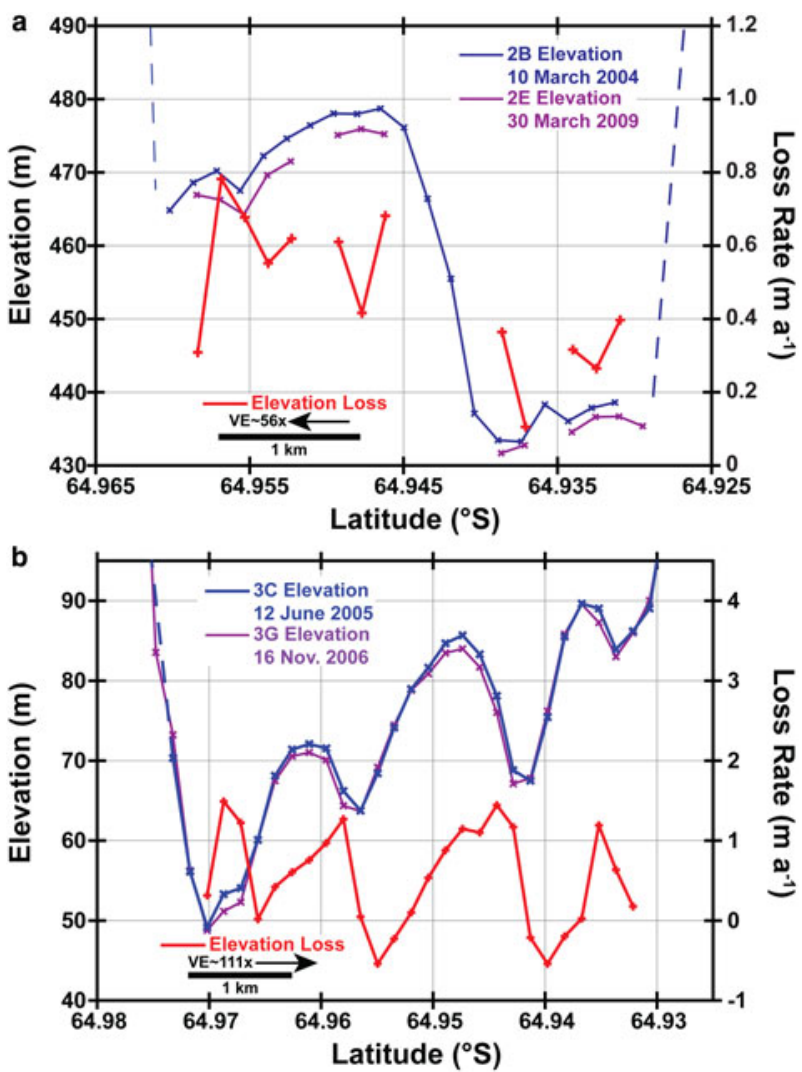

Fig. 5. ICESat repeat altimetry profiles and derived elevation loss rates for the Rogosh Glacier (RG) (see Fig. 1). Figure 5a shows the data where ICESat Track 0248 crosses the middle part of the branching RG nearly perpendicularly. Figure 5b shows the data where ICESat Track 0256 obliquely crosses the lower RG's rough topography. Dashed lines indicate approximately where the valley walls were located and these plots have different axis ranges. Missing altimetry data are indicated by gaps in the plotted data. ICESat's direction is indicated with the black arrow and the degree of vertical exaggeration (VE) of the elevation data is shown. The black bars indicate $1 \mathrm{~km}$ in distance.

observed. These rifts do not hold water even when surface melt is evident nearby and lead to the release of icebergs from this area. The imagery also shows older undulations that frequently held melt water during the study period. Based on their orientation, these tight undulations must have formed by the convergence of ice from adjacent glaciers (Fig. 1 and Fig. 4a). We infer that since the new rifts cut across the older ones, the open rifts reflect new stresses on the ice shelf remnant.

Several of the SNIS ICESat profiles show the occurrence of ice edge retreat, but all indicate significant net elevation changes (Fig. 2). For example, ICESat Track 0367 data (Fig. 2b) shows the vertical scale of the changes near the widest part of the SNIS. This portion of SNIS is not within the area of embedded nunataks but is where successive icebergs calved during the study period as is suggested by the repeat altimetry profiles and Figure 1. MODIS imagery from 3 March 2000 shows the presence of the large rifts that produced these icebergs, indicating they were probably a response to loss of buttressing from the Larsen A ice shelf following the collapse in 1995 (Ferrigno and others, 2006; Cook and Vaughan, 2010). The icebergs calved from the north side of the shelf remnant in 2004/05 (Shuman and others, 2011). The profiles for Tracks 0256 and 0375 show smaller iceberg losses. Other small calving events are indicated in Figure 1 such as the ice area lost between Castor Nunatak (Ca.) and RI. By combining imagery data (Table 2, MODIS) and all ICESat profiles (Table 3), the timing of these ice area losses of shelf ice can be constrained.

\section{Floating ice elevation and thickness changes}

The ICESat repeat altimetry allows comparisons of elevation changes for several parts of the SNIS remnant. Bathymetric data adjacent to the shelf areas crossed by the profiles (Lavoie and others, 2015) show that the shelves are afloat at least at the edges, and distinct grounding lines in InSAR, MODIS and Landsat 7 image data far from the shelf edges show that the ICESat track areas are largely afloat (Rack and others, 1999; Haran and others, 2005; Bindschadler and others, 2011).

Figure 2 shows the first and last altimetry profile for each of the four SNIS tracks as well as the derived loss rate across the remaining shelf remnant from those two tracks. Lateral offsets between the track pairs shown in Figure 2 ranged between $14 \mathrm{~m} \mathrm{(0256)}$ and $111 \mathrm{~m} \mathrm{(0367)} \mathrm{and} \mathrm{averaged} 55 \mathrm{~m}$. Using a 5-shot smoothed, average along-track slope value from Track 0367 suggests the cross track distance at Track 0367 could cause at most $\sim 0.065 \mathrm{~m}$ of elevation difference, or $\sim 5 \%$ of the observed $1.43 \mathrm{~m}$ net elevation change. The shape of the loss rate data (red lines in Fig. 2) suggests slightly greater losses at the exposed ice fronts of the shelf remnant (Tracks 0367 and 1349) but the data are less diagnostic for Tracks 0256 and 0375.

The slope of the regression line for all ICESat repeat track data was used to calculate the elevation loss rates in Table 4 for each track location. The altimetry profile pairs shown in Figure 2 illustrate the pattern of the elevation change. Given the sparse temporal record of the altimetry profiles, it was not possible to assess any seasonal elevation variations but we believe those effects must be small. Single-profile elevation uncertainty, indicated by error bars in Figure 3, are based on Pritchard and others (2012, Supplementary Information, Section $1.4( \pm 0.275 \mathrm{~m}))$. The similarity of the trends for the four different SNIS profiles increases confidence in these results.

Table 4 shows the elevation loss rates and derived ice shelf thinning rates for each SNIS track. Our calculated rates are about twice the values reported in Pritchard and others (2012; Personal communication from Pritchard, 2014) as discussed further below. However, our individual track analyses provide consistent results across the ice shelf remnant (Table 4, Fig. 1) and an overall estimated mean elevation loss of $0.29 \mathrm{~m} \mathrm{a}^{-1}$ and a mean thinning of $2.32 \mathrm{~m} \mathrm{a}^{-1}$.

Significant differences in firn compaction estimates from modeling results versus field observations seem to explain why our loss rates are markedly higher than earlier work. Modeling data for the Larsen B (Pritchard and others, 2012 Supplementary Information, Table 1) suggests there is 0.16 $\mathrm{m} \mathrm{a}^{-1}$ elevation lowering on the nearby Larsen B remnant attributed to firn compaction. As noted, this is inconsistent with field observations of solid ice in the upper meter of the SIIS surface during field work (TAS, February 2010), analysis of the mean density of the entire shelf (Holland and others, 2011) and the satellite image record of extensive melt ponding in the area since the mid-1980s (Scambos and others, 2003). 


\section{Grounded ice elevation changes}

Quantifying the elevation changes for RI was achieved by using a pair of ICESat repeat profiles with overlapping footprints (mean offset was $38 \mathrm{~m}$ ) as well a DEM derived from a pair of ASTER images (Table 2) as discussed further below. During the same overall study period for the SNIS, repeated ASTER imagery showed that $\mathrm{RI}^{\prime} \mathrm{s}$ ice margins retreated up to $\sim 0.5 \mathrm{~km}$, primarily on the northern margin (Fig. 4a and Table 2). The limited retreat observed in the imagery suggests that the majority of $\mathrm{RI}$ is covered in grounded ice.

The RI ice cap became separated from adjacent major ice shelves in the late 1990s (Ferrigno and others, 2008, Map I2600-B) following major retreats of the Larsen A and B ice shelves. Our imagery analysis distinguished RI from the SNIS remnant by a subtle slope break (see the section SNIS ice shelf area changes) and indicates the ice cap reduced in area from $166.3 \mathrm{~km}^{2}$ in 2001 to $159.2 \mathrm{~km}^{2}$ in 2012. The net loss is $\sim 7 \mathrm{~km}^{2}$ with an estimated uncertainty of $\sim 2 \mathrm{~km}^{2}$ because the ASTER imagery cannot exactly define the RI interface position with the SNIS. The small area change and absence of calving suggests that the RI ice cap is grounded.

Plotting the elevations and the derived differences of the first and last Track 0003 profiles across RI, 22 February 2004 (2B) and 14 March 2009 (2E) (Table 3), illustrates significant changes in the ice cap's topography (Fig. 4b). The difference data from these profiles also defines a variable loss rate across $\mathrm{RI}$. This ranges from $\sim 1 \mathrm{~m} \mathrm{a}^{-1}$ on the south side to $<0.5 \mathrm{~m} \mathrm{a}^{-1}$ at the summit ridge to a maximum of nearly $4 \mathrm{~m} \mathrm{a}^{-1}$ in a topographic 'bowl' on the northeastfacing side of RI. Table 4 shows the mean elevation loss and loss rate derived from the two profiles as well as a larger uncertainty value (see the section Satellite laser altimetry) derived from the standard deviations of the differences from a portion of the RI data.

In addition, all the Track 0003 profiles (Table 2) were differenced using a 2005 ASTER DEM to account for cross-track slope variations between the offset altimetry profiles (after Moholdt and others, 2010). Track spacing in the full set of the clear Track 003 profiles ranged up to $350 \mathrm{~m}$. Net elevation change between profiles was assessed using a regression line through the mean elevation differences from the DEM for each repeat profile. The difference between those results and the mean elevation loss from the first-last (F-L) analysis shown in Figure $4 \mathrm{~b}$ was $0.04 \mathrm{~m} \mathrm{a}^{-1}$, with the DEM-based result being smaller. This indicates that our results for small footprint-offset passes are consistent with methods that apply a cross-slope correction (e.g., Scambos and others, 2014). Note, for the analysis in this study, we filtered less of the ICESat data on RI than in the 2014 study. This produces a slightly more negative elevation change rate $\left(-1.76 \mathrm{~m} \mathrm{a}^{-1}\right.$, Table 4) than was reported in the earlier study $(-1.54 \mathrm{~m}$ $\mathrm{a}^{-1}$ ) (Scambos and others, 2014, supplement, Basin 26b).

Rogosh Glacier (RG), the last remaining tributary to the western end of SNIS is crossed in two places by ICESat track data (Tracks 0248 and 0256, Fig. 1 and Table 3) but the altimetry data are sparse due to clouds. Figure 5 shows the elevations of the closest pair of profiles for Tracks 0248 and 0256 both inland of the GL (Fig. 1). The derived loss rates are noisy in part due to the topography of RG. Altimetry data gaps, likely due to clouds, impacted the $2 \mathrm{E}$ data for 0248 (Fig. 5a) and the inland portion of Track
0256 (e.g. Fig. 2a) was not available due to clouds after November 2006 (Table 3).

The Track 0248 data reveal a difference in both topography and elevation loss rate across the upper part of this tributary glacier. These altimetry profiles cross the RG almost perpendicular to flow (Fig. 1) and are also just above the point where the glacier bifurcates. The 0248 elevation difference data indicate that RG may be losing more ice through a short, steep southern outlet into a bay within the Larsen B embayment west of Cape Fairweather. MODIS data indicate this area lost its shelf ice remnant $\left(\sim 44 \mathrm{~km}^{2}\right.$ in 2002, Fig. 1) during early 2004 and the ETM + imagery from 2008 show that the embayment extended well inland past the R\&R-GL by that time. This loss of buttressing appears to have increased ice flow in the southern outlet, and may have caused an increase in the elevation loss rate in the ICESat profile in that sector relative to the main RG channel flowing toward the SNIS. Comparing the left side of Figure 5 a to the right side shows that the southern side of the RG is losing elevation at 0.58 $\mathrm{m} \mathrm{a}^{-1}$ whereas the lower, northern side is losing elevation at $0.29 \mathrm{~m} \mathrm{a}^{-1}$. Further, the southern outlet's loss rate at Track 0248 is slightly greater than the mean loss rate for the main channel of the RG from the Track 0256 data $\left(0.53 \mathrm{~m} \mathrm{a}^{-1}\right.$, Table 4). From the available data, we cannot define when increased ice flow to the south began but the ETM + imagery series suggests that crevasses were more apparent in the ice moving south from the RG by 2008.

These ICESat data were not sufficient to calculate a basinwide $\mathrm{dH} / \mathrm{dt}$. Consequently, the Scambos and others (2014) analysis relied on DEM data to estimate net losses of 1.52 $\mathrm{m} \mathrm{a}^{-1}$ for the whole RG basin (see their Table S2, Basin 26a). The upper RG results from Track 0248 (both north and south) and the lower RG results from Track 0256 are both smaller than this area-averaged value, yet our results are not inconsistent with the overall basin analysis (Table 4). This is due to large loss rates derived from the DEM differencing results that extended the Scambos and others (2014) analysis to areas not profiled by ICESat. Close examination of Figure 2 from Scambos and others (2014) shows high losses $\left(\sim 8 \mathrm{~m} \mathrm{a}^{-1}\right)$ for the lower part of the southern outlet of RG. A similar loss rate was derived for the lower part of a small unnamed glacier on the northern side of the overall RG basin area similarly exposed after the iceberg losses in 2004/05 from the north side of the SNIS. Though not definitive, the differential losses across Track 0248, with large losses from the published DEM-differencing plus more visible crevassing on the southern outlet seen in the imagery sequence, suggest this branch of RG may be decreasing the amount of ice reaching the SNIS.

\section{Partitioning surface and basal melting}

The combined RG and RI grounded ice elevation loss data suggest an approximate regional magnitude of the atmospherically-driven ablation rates for the SNIS region. With losses of more than $0.5 \mathrm{~m} \mathrm{a}^{-1}$ in the lower RG (Fig. 5b) and measured losses averaging $1.7 \mathrm{~m} \mathrm{a}^{-1}$ for the lowest $\sim 70 \mathrm{~m}$ of the RI Track 0003 data (Fig. 4b, combining both north and south side RI data), we infer a magnitude of the atmospherically-driven thinning across the study area at elevations close to sea level as discussed below. Velocity data from Rack and others (1999) is compatible with a more extensive compilation by Rignot and others (2011) and shows 
shelf ice velocities on the order of $25 \mathrm{~m} \mathrm{a}^{-1}$ or lower for the shelf areas suggesting that dynamic changes to the floating ice shelf are negligible. Table 4 shows the estimated thinning rates for the four ICESat tracks across the SNIS when the surface elevation change of this dense floating ice is converted to ice thickness. These data suggest that the floating ice thinning rate has a slight increase from west to east from the SNIS profiles.

We contrast the thinning estimated at Track 1349 $\left(2.74 \mathrm{~m} \mathrm{a}^{-1}\right)$ with the below $70 \mathrm{~m}$ elevation losses from nearby Track 0003 on RI $\left(1.70 \mathrm{~m} \mathrm{a}^{-1}\right)$ that has similarly low flow velocities (Rignot and others, 2011). A ratio of the ice cap losses to the nearest ice shelf losses suggests that the atmospheric contribution to the shelf losses is $\sim 62 \%$ of the total with $\sim 38 \%$ due to subsurface oceanic melting. As a further test, we contrasted the estimated thinning in the lower RG below Track 0256 (Fig. 5b, Table 4 assuming it increases to the mean of the loss rates on the lower RG data and those below $70 \mathrm{~m}$ elevation on $\mathrm{Rl}$; the mean of 0.53 and 1.70 is $1.12 \mathrm{~m} \mathrm{a}^{-1}$ ) with the thinning at the Track 0367 location $\left(2.39 \mathrm{~m} \mathrm{a}^{-1}\right)$, which suggests that the atmosphere contributes $47 \%$ of the overall thinning and the ocean the other $53 \%$.

In both cases, the estimated ocean contribution to shelf thinning is $\sim 1 \mathrm{~m} \mathrm{a}^{-1}$, which is compatible with basal thinning reported further south in Holland and others (2015). It is important to note that the number of nunataks as well as a limited amount of adjacent bathymetry data (Lavoie and others, 2015) both indicate that the water depths in the area are shallow ( $\sim 300 \mathrm{~m}$ or less). This suggests that the basal thinning seen for the remnant shelf profiles may be due to tidal fluxing of a near-surface ocean layer, and not to incursion of deeper oceanographic water types. Similar behavior, i.e. increased basal melt inferred to be a result of tidal fluxing of solar-warmed surface water, has been reported for the McMurdo Ice Shelf ice front (Stern and others, 2013).

\section{CONCLUSIONS}

Analysis of imagery and altimetry at multiple locations across the SNIS since 2002 indicates that ongoing ice shelf losses are significant in both area and thickness. Comparison of grounded and ungrounded ICESat-derived elevation loss data across the study area suggests that $50-60 \%$ of SNIS thinning is due to atmospheric warmth and related surface processes and $40-50 \%$ is due to the underlying ocean's tides and currents. The combined altimetry and imagery analysis also indicates that the overall thinning is not due to shelf ice spreading as edge positions are observed to be nearly motionless between ICESat campaigns when satellite imagery indicates no calving has occurred (Fig. 1, Figs 2b, d). This is compatible with velocity assessments as flow speeds for the SNIS are generally low, about or below $25 \mathrm{ma}^{-1}$ (Rignot and others, 2011) except for the small unbuttressed outlets north and south of where the SNIS meets the nAP. We therefore conclude that dynamic losses are not a factor at the ICESat locations studied.

The generally increasing from west to east and highest ICESat-derived thinning at Track 1349 may indicate more effective overall thinning processes in areas away from the nAP coast. The SNIS's incompletely known underlying bathymetry is also likely a factor in the variable thinning rates. Further, the low elevation of the shelf margin $(\sim 10 \mathrm{~m})$ along Track 1349 at the northeastern side of the shelf (Fig. 3), the formation of multiple open rifts and calving losses on both sides of SNIS between Pollux Nunatak (Po.), Castor (Ca.) Nunatak, and RI (Fig. 4a) suggests this portion of the remnant may detach from RI in the near future.

Strongly asymmetric losses across the RI show the importance of slope aspect to surface melt ice losses. This asymmetry also suggests the difficulty of deriving area losses from single ICESat repeat tracks. This is further emphasized by the limited elevation change data from ICESat on the RG where even small footprint offsets in rough topography can cause distinct variations in elevation change data. It is important to note that even with these caveats, losses from and changes to the adjacent grounded ice of RI and RG broadly parallel our measured changes on the SNIS with increasing average losses from west to east across the study area. In addition, the differential loss of ice from the upper RG, apparently due to an unbuttressed, secondary outlet flowing to the south, indicates that there is probably less ice reaching the SNIS than in the past.

With less ice reaching the shelf remnant, and with extensive surface melt apparent in most austral summers, margin retreats and new rifting and an average thinning rate of more than $2 \mathrm{ma}^{-1}$, it appears unlikely that the SNIS remnant will persist for many more years. But it is not clear if the recent local cooling suggested by LARISSA temperature observations (Cape and others, 2015) and more persistent sea ice in the area since early 2008 relative to the preceding decade, as seen in MODIS images, will slow or possibly stabilize the area's ice losses. In summary, as with the nearby SIIS (Khazendar and others, 2015; Wuite and others, 2015), there appear to be poor prospects for the SNIS's future.

\section{ACKNOWLEDGEMENTS}

The authors would like to acknowledge the support of $H$. Pritchard for additional insights on a previously published analysis for the area (Pritchard and others, 2012). The authors would also like to thank J. Bohlander, K. Melocik, V. Suchdeo, and P. Vornberger for help with aspects of the imagery analysis. This project also benefitted from the help of M. Siegfried and L. Padman regarding the best available ocean tide model for the ICESat data. The ICESat data for this paper are available at the NASA Distributed Active Archive Center at the National Snow and Ice Data Center (GLA12 - GLAS/ICESat L2 Antarctic and Greenland Ice Sheet Altimetry Data). The Landsat data were acquired at no cost via the Earth Explorer website from the US Geological Survey's Earth Resource Observation and Science Center (EROS), home of the national archive for Landsat imagery. The ASTER data were provided at no cost through the Global Land Ice Measurements from Space (GLIMS) project. This work was supported by NSF and NASA grants to T. Scambos (NSF ANT-0732921; NASA NNX10AR76G), the TOSCA and ISIS programs of the French Space Agency (CNES) to E. Berthier, and NASA Cryospheric Sciences Program funds to C. Shuman. The final paper benefitted from the many helpful comments provided by two anonymous reviewers.

\section{REFERENCES}

Berthier E, Scambos TA and Shuman CA (2012) Mass loss of Larsen B tributary glaciers (Antarctic Peninsula) unabated since 2002. Geophys. Res. Lett., 39, L13501 (doi: 10.1029/2012GL051755) 
Bindschadler R and 17 others (2011) Getting around Antarctica: new high-resolution mappings of the grounded and freely-floating boundaries of the Antarctic Ice Sheet created for the International Polar Year. Cryosphere, 5, 569-588 (doi: 10.5194/tc-5-569-2011)

Borsa AA, Moholdt G, Fricker HA and Brunt KM (2014) A range correction for ICESat and its potential impact on ice-sheet mass balance studies. Cryosphere, 8, 345-357 (doi: 10.5194/tc-8345-2014)

Cape MR and 5 others (2015) Foehn winds link climate-driven warming to ice shelf evolution in Antarctica. J. Geophys. Res.: Atmospheres, 120(21), 11,037-11,057 (doi: 10.1002/ 2015JD023465)

Cook AJ and Vaughan DG (2010) Overview of areal changes of the ice shelves on the Antarctic Peninsula over the past 50 years. Cryosphere, 4, 77-98 (doi: 10.5194/tc-4-77-2010)

Cook AJ, Fox AJ, Vaughan DG and Ferrigno JG (2005) Retreating glacier fronts on the Antarctic Peninsula over the past halfcentury. Science, 308(5721), 541-544 (doi: 10.1126/ science.1104235)

Depoorter MA and 6 others (2013) Calving fluxes and basal melt rates of Antarctic ice shelves. Nature, 502(7469), 89-92 (doi: 10.1038/nature12567)

Ferrigno JG and 7 others (2006) Coastal-change and glaciological map of the Trinity Peninsula area and South Shetland Islands, Antarctica - 1843-2001: U.S. Geological Survey Geologic Investigations Series Map 1-2600-A, 1 map sheet, 32-p. text

Ferrigno JG and 7 others (2008) Coastal-change and glaciological map of the Larsen Ice Shelf area, Antarctica: 1940-2005: U.S. Geological Survey Geologic Investigations Series Map I-2600$B, 1$ map sheet, 28-p. text

Glasser NF and 5 others (2011) From ice-shelf tributary to tidewater glacier: continued rapid recession, acceleration and thinning of Röhss Glacier following the 1995 collapse of the Prince Gustav Ice Shelf, Antarctic Peninsula. J. Glaciol., 57(203), 397-406 (doi: 10.3189/002214311796905578)

Global Volcanism Program (1982) Report on Seal Nunataks Group (Antarctica). In McClelland L ed. Scientific event alert network bulletin, Vol. 7, 9. Washington, DC, USA: Smithsonian Institution (doi: 10.5479/si.GVP.SEAN198209-390050)

González-Ferrán O (1983) The Larsen Rift: an active extension fracture in West Antarctica. In Oliver R, James $\mathrm{P}$ and Jago J eds. Antarctic Earth Science. Cambridge University Press, Melbourne, 344-346

Griggs JA and Bamber JL (2009) Ice shelf thickness over Larsen C, Antarctica, derived from satellite altimetry. Geophys. Res. Lett., 36, L19501 (doi: 10.1029/2009GL039527)

Griggs JA and Bamber JL (2011) Antarctic ice-shelf thickness from satellite radar altimetry. J. Glaciol., 57(203), 485-498 (doi: 10.3189/002214311796905659)

Haran T, Bohlander J, Scambos TA, Painter T and Fahnestock $M$ (2005) updated 2013, MODIS Mosaic of Antarctica 2003-2004 (MOA2004) Image Map, Version 1, [Antarctic Peninsula], Boulder, Colorado, USA: National Snow and Ice Data Center (doi: 10.7265/N5ZK5DM5)

Hofton MA, Luthcke SB and Blair JB (2013) Estimation of ICESat intercampaign elevation biases from comparison of lidar data in East Antarctica. Geophys. Res. Lett., 40, 5698-5703 (doi: 10.1002/2013GL057652)

Holland PR and 6 others (2011) The air content of Larsen ice shelf. Geophys. Res. Lett., 38, L10503 (doi: 10.1029/2011GL047245)

Holland PR and 6 others (2015) Oceanic and atmospheric forcing of Larsen C Ice-Shelf thinning. Cryosphere, 9, 1005-1024 (doi: 10.5194/tc-9-1005-2015)

Khazendar A, Borstad CP, Scheuchl B, Rignot E and Seroussi H (2015) The evolving instability of the remnant Larsen B Ice Shelf and its tributary glaciers. Earth Planet. Sci. Lett., 419, 199-210 (doi: 10.1016/j.epsl.2015.03.014)

Korona J, Berthier E, Bernard M, Remy F and Thouvenot E (2009) SPIRIT. SPOT 5 stereoscopic survey of polar ice: reference images and topographies during the fourth International Polar
Year (2007-2009). ISPRS J. Photogr. Remote Sens., 64(2), $204-$ 212 (doi: 10.1016/j.isprsjprs.2008.10.005)

Kwok R, Zwally HJ and Yi D (2004) ICESat observations of Arctic sea ice: a first look. Geophys. Res. Lett., 31, L16401 (doi: 10.1029/ 2004GL020309)

Lavoie C and 11 others (2015) Configuration of the Northern Antarctic Peninsula Ice Sheet at LGM based on a new synthesis of seabed imagery. Cryosphere, 9, 613-629 (doi: 10.5194/tc-9613-2015)

Moholdt G, Nuth C, Hagen JO and Kohler J (2010) Recent elevation changes of Svalbard glaciers derived from repeat track ICESat altimetry. Remote Sens. Environ., 114(11), 2756-2767 (doi: 10.1016/j.rse.2010.06.008)

Nield GA and 8 others (2014) Rapid bedrock uplift in the Antarctic Peninsula explained by viscoelastic response to recent ice unloading. EPSL, 397, 32-41 (doi: 10.1016/j.eps1.2014.04.019)

Paolo FS, Fricker HA and Padman L (2015) Volume loss from Antarctic ice shelves is accelerating. Science, 348(6232), 327331 (doi: 10.1126/science.aaa0940)

Pritchard HD and 5 others (2012) Antarctic ice-sheet loss driven by basal melting of ice shelves. Nature, 484, 502-505 (doi: 10.1038/nature10968)

QGIS Development Team (2015) QGIS Open Source Geographic Information System, version 2.10.1, 'Pisa'. Open Source Geospatial Foundation project. http://qgis.osgeo.org

Rack W and Rott H (2004) Pattern of retreat and disintegration of the Larsen B ice shelf. Antarctic Peninsula. Ann. Glaciol., 39, 505510 (doi: 10.3189/172756404781814005)

Rack W, Rott H, Siegel A and Skvarca P (1999) The motion field of northern Larsen ice shelf derived from satellite imagery. Ann. Glaciol., 29, 261-266 (doi: 10.3189/172756499781821120)

Rignot E (2006) Changes in ice dynamics and mass balance of the Antarctic ice sheet. Phil. Trans. R. Soc. A Math. Phys. Eng. Sci., 364(1844), 1637-1655 (doi: 10.1098/rsta.2006.1793)

Rignot E and 5 others (2004) Accelerated ice discharge from the Antarctic Peninsula following the collapse of Larsen B ice shelf. Geophys. Res. Lett., 31, L18401 (doi: 10.1029/2004GL020697)

Rignot E, Mouginot J and Scheuchl B (2011) Ice flow of the Antarctic ice sheet. Science, 333(6048), 1427-1430 (doi: 10.1126/ science.1208336)

Rignot E, Jacobs S, Mouginot J and Scheuchl B (2013) Ice-shelf melting around Antarctica. Science, 341(6143), 266-270 (doi: 10.1126/science.1235798)

Rott H, Skvarca P and Nagler T (1996) Rapid collapse of northern Larsen Ice Shelf, Antarctica. Science, 271(5250), 788-792 (doi: 10.1126/science.271.5250.788)

Rott H, Müller F, Nagler T and Floricioiu D (2011) The imbalance of glaciers after disintegration of Larsen-B ice shelf, Antarctic Peninsula. Cryosphere, 5, 125-134 (doi: 10.5194/tc-5-125-2011)

Scambos TA, Bohlander J and Raup B (1996) Images of Antarctic Ice Shelves [Larsen B: 2000 to 2015]. Boulder, Colorado, USA: National Snow and Ice Data Center (doi: 10.7265/N5NC5Z4N)

Scambos TA, Hulbe C, Fahnestock M and Bohlander J (2000) The link between climate warming and break-up of ice shelves in the Antarctic Peninsula. J. Glaciol., 46(154), 516-530 (doi: 10.3189/172756500781833043)

Scambos TA, Hulbe CL and Fahnestock M (2003) Climate-induced ice shelf disintegration in the Antarctic Peninsula. In Domack $E$, Leventer A, Burnett A, Bindschadler R, Convey P and Kirby M eds. Antarctic peninsula climate variability; historical and paleoenvironmental perspectives, Vol. 79. Antarctic Research Series, AGU, Washington, DC, 79-92 (doi: 10.1029/AR079p0079)

Scambos TA, Bohlander JA, Shuman CA and Skvarca P (2004) Glacier acceleration and thinning after ice shelf collapse in the Larsen B embayment, Antarctica. Geophys. Res. Lett., 31, L18402 (doi: 10.1029/2004GL020670)

Scambos TA, Sergienko O, Sargent A, MacAyeal D and Fastook J (2005) ICESat profiles of tabular iceberg margins and iceberg breakup at low latitudes. Geophys. Res. Lett., 32, L23S09 (doi: 10.1029/2005GL023802) 
Scambos TA, Ross R, Haran T, Bauer R and Ainley DG (2013) Instruments and Methods: A camera and multisensor automated station design for polar physical and biological systems monitoring: AMIGOS. J. Glaciol., 59(214), 303-314 (doi: 10.3189/ 2013JoG12J170)

Scambos TA and 6 others (2014) Detailed ice loss pattern in the northern Antarctic Peninsula: widespread decline driven by ice front retreats. Cryosphere 8, 2135-2145 (doi: 10.5194/tc-8-21352014)

Schutz BE, Zwally HJ, Shuman CA, Hancock D and DiMarzio JP (2005) Overview of the ICESat Mission. Geophys. Res. Lett., 32, L21S01 (doi: 10.1029/2005GL024009)

Schutz R, DiMarzio J, Luthcke S, Hancock D and Urban T (2011) Notice concerning detection of ICESat inter-campaign elevation biases. https://nsidc.org/sites/nsidc.org/files/files/inter-campaign bias_notice_v1.pdf

Seehaus T, Marinsek S, Helm V, Skvarca P and Braun M (2015) Changes in ice dynamics, elevation and mass discharge of DinsmoorBombardier-Edgeworth glacier system, Antarctic Peninsula. Earth Planet. Sci. Lett., 427, 125-135 (doi: 10.1016/j.epsl.2015.06.047)

Shepherd A, Wingham D, Payne T and Skvarca P (2003) Larsen ice shelf has progressively thinned. Science, 302(5646), 856-859 (doi: 10.1126/science.1089768)
Shuman CA and 6 others (2006) ICESat Antarctic elevation data: preliminary precision and accuracy assessment. Geophys. Res. Lett., 33(L07501) (doi: 10.1029/2005GL025227)

Shuman CA, Berthier E and Scambos TA (2011) 2001-2009 elevation and mass losses in the Larsen A \& B embayments, Antarctic Peninsula. J. Glaciol., 57(204), 737-754 (doi: 10.3189/002214311797409811)

Stern AA, Dinniman MS, Zagorodnov V, Tyler SW and Holland DM (2013) Intrusion of warm surface water beneath the McMurdo Ice Shelf, Antarctica. J. Geophys. Res.-Oceans, 118(12), 7036-7048 (doi: 10.1002/2013jc008842)

van den Broeke M (2005) Strong surface melting preceded collapse of Antarctic Peninsula ice shelf. Geophys. Res. Lett., 32(12) (doi: 10.1029/2005GL023247)

van Wessem JM and 10 others (2016) The modeled surface mass balance of the Antarctic Peninsula at $5.5 \mathrm{~km}$ horizontal resolution. Cryosphere, 10, 271-285 (doi: 10.5194/tc-10-271-2016)

Vaughan DG and Doake CSM (1996) Recent atmospheric warming and retreat of ice shelves on the Antarctic Peninsula. Nature, 379, 328-331 (doi: 10.1038/379328a0)

Wuite $\mathrm{J}$ and 7 others (2015) Evolution of surface velocities and ice discharge of Larsen B outlet glaciers from 1995 to 2013 Cryosphere 9, 957-969 (doi: 10.5194/tc-9-957-2015) 